\title{
Analysis of Pigments in the Buseoksa Josadang Murals in Yeongju
}

\author{
You Na Song ${ }^{1, *}$, Han Hyoung Lee', Na Yeon Baek ${ }^{1}$, Cham Hee Jung ${ }^{2}$, Min Jeong Park ${ }^{3}$, Yong Jae Chung ${ }^{1}$ \\ ${ }^{1}$ CON-TECH, Korea National University of Cultural Heritage, Buyeo 33115, Korea \\ ${ }^{2}$ Department of Conservation and Artbank, National Museum of Modern and Contemporary Art, Cheongju 28501, Korea \\ ${ }^{3}$ Graduate School of Cultural Heritage, Korea National University of Cultural Heritage, Buyeo 33115, Korea
}

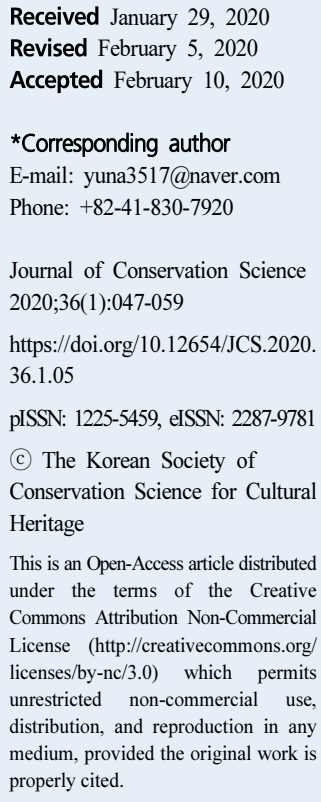

\begin{abstract}
Scientific analysis was conducted to identify the paint pigments used in the Buseoksa Josadang murals. optical microscopy(OM), X-ray fluorescence(XRF), XRF mapping, scanning electron microscopy-energy dispersive X-ray spectroscopy(SEM-EDS), and Raman spectroscopy were performed to examine the pigments. The results confirmed that the Josadang murals consist of two paint layers wherein the pigments were distinct for most colors. It was estimated that celadonite, white clay, red ochre, cinnabar and minium, synthetic green pigment containing tin and zinc paratacamite, or botallackite were used in the upper layer. In addition, bone white, celadonite, red ochre, azurite, cinnabar or vermilion, and gold were identified in the lower layer. In addition, as $\mathrm{Zn}$ and $\mathrm{Sn}$ were detected in the green pigments extracted from the top layer of the paint, it is believed that Josadang murals were repainted over the original paint layer at some point after the 17 th century. In addition, white pigments containing calcium phosphate were found in all the colors in the bottom layer, which is the original paint layer. These results are significant because this is the first time that white pigments are found in Korean traditional paintings. Additionally, the information revealed about the pigments in this study will serve as areference for the pigments used in the Goryeo period.
\end{abstract}

Key Words Murals, Pigments, Goryeo period, Painting layer, Calcium phosphate

\section{INTRODUCTION}

The Josadang murals(National treasure No. 46) stored at the Sungbo Museum of Buseoksa in Yeongju, Gyeongsangbukdo, South Korea are the only murals from the Goryeo period in existence today. Most of the existing Buddhist temple murals in Korea were painted after the mid-Joseon period, while the Josadang murals at Buseoksa, Yeongju, Daeungjeon murals at Sudeoksa, Yesan, Daeungjeon murals at Bongjeongsa, Andong, and Geungnakjeon murals at Muwisa, Gangjin are known to have been painted prior to mid-Joseon period. Of these, the Josadang murals at Buseoksa are the earliest and the only ones painted during the Goryeo period(3rd year of the reign of King U, 1377) and are, therefore, particularly significant for the study Korean Buddhist temple murals.

Previous studies of the pigments in Korea were conducted primarily for the paintings created after the 17th century, in the mid-Joseon period. When many cultural artifacts were damaged during the Japanese and the Second Manchu invasions of Joseon, both movable cultural properties, such as Buddhist paintings and portraits, and immovable properties, such as dancheong(traditional Korean decorative coloring on wooden buildings) and Buddhist temple murals, were lost to fire. They were painted again when Buddhist temples were rebuilt or repaired across the country. 
Scientific studies published on Buddhist temple murals in Korea include X-ray diffraction analysis of Kumsansa mural Painting and Danchong(Hong and Chung, 1992), the analysis study of mural painting pigments at Pongjongsa Kuknakjon(II)(Cho et al., 2000), comparative study on the pigments applied on the wall paintings of temple in 18-19C(Son et al., 2013), pigment analysis and nondestructive deterioration diagnosis of the wall paintings in Gwanyongsayaksajeon(Yaksajeon Hall of Gwanyongsa Temple), Changnyeong, Korea(Chun et al., 2009), and pigment analysis for wall paintings according to verification of penetration depth for X-ray: Ssanggyesa Daeungjeon(main hall of Ssanggyesa temple) in Nonsan(Chun et al., 2011). Several ongoing projects are being carried out to preserve and document Buddhist temple murals and research is being conducted continuously for the Geungnakjeon Amitabha Buddha triad mural and the white-robed Avalokitesvara painting at Muwisa, Gangjin, Geungnakjeon murals at Daewonsa, Boseong, the Buddhist scroll painting at Magoksa, Gongju, and the Geungnakjeon Buddhist mural at Wibongsa, Wanju. However, most Buddhist temple murals were painted in the late Joseon period after the Japanese invasions and only limited records are available regarding the materials used in the murals that were painted prior to the late Joseon period. Hence, findings about the paint pigments in the Josadang murals will provide important evidence for examining the use of pigments from the late Goryeo period to the early Joseon period.

The Josadang murals were first treated for preservation by Japan during the 1920 s, and this was followed by short-term form of the treatments in 1984 and 2002. However, a precise scientific analysis of these murals was first conducted only in 2018 and focused on preservation conditions of murals, structural safety diagnosis, and paint pigments along with the materials of wall(Buseoksa et al., 2018). The present study is a continuation of this research and aims to analyze the paint pigments and to identify the types of pigments used in the murals.

\section{EXPERIMENT}

\subsection{Objects}

The Buseoksa Josadang murals consist of six paintings on each wall: East Virūọhaka, West Virūḍhaka, South Virūụhaka, North Virūụhaka, Śakra, and Brahmā(Figure 1). Each mural has dimensions of $72-81 \mathrm{~cm} \times 209-212 \mathrm{~cm}$ and was originally painted in the inner wall. Subsequently, the murals were removed from the walls and placed on a wooden frame during the preservation in the 1920s and have been kept in this state to date.

In all six murals, traces of inscriptions are still present at the top of each mural, and small cracks in random directions, along with six large cracks at consistent intervals in the horizontal direction, have formed. The cracks and some parts of the walls that fell off were replaced with white pigment as repair materials. The remaining parts of the murals were in poor condition with a substantial portion of the paint layer chipped off and the bottom background layer exposed. In this work, optical microscopy, X-ray fluorescence(XRF)
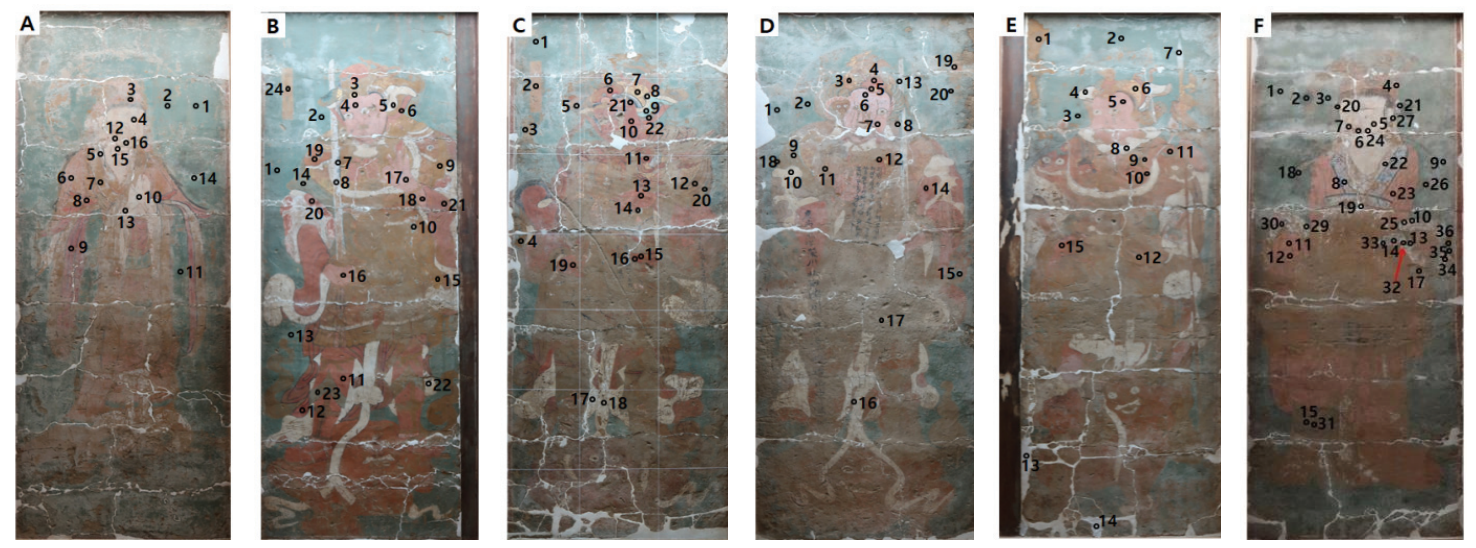

Figure 1. Objects and XRF analysis points; (A) Śakra painting(BSJ-M-1), (B) West Virūḍhaka(BSJ-M-2), (C) South Virūụhaka(BSJ-M-3), (D) East Virūụhaka(BSJ-M-4), (E) North Virūụhaka(BSJ-M-5), (F) Brahmā(BSJ-M-6). 
spectroscopy, and XRF mapping were used to analyze the paint pigments in the murals. To observe the paint layers of the murals and identify their pigment materials, samples were collected for each color and analyzed using scanning electron microscopy-energy dispersive X-ray spectroscopy(SEM-EDS) and Raman spectroscopy.

\subsection{Optical microscopy}

For optical microscopy, a hand-held digital microscope (Digital Microscope, Scalar Corp. DG-3, Japan) was used to observe the particle size and mixture of the pigments at the magnifications of $\times 30, \times 100$, and $\times 200$. Here, $\times 30$ magnification was used to determine the murals' painting technique and overlap with surrounding colors, while $\times 100$ and $\times 200$ magnifications were used to analyze the presence of the particles in the pigments, the particle shape, and the mixture of the pigments.

\subsection{X-ray fluorescence spectroscopy}

A portable X-ray fluorescence spectrometer(Titan Tracer 5i, Bruker, DEU and Vanta, Olympus, JPN) was used to analyze the elements in the pigments. The analysis was conducted on the relatively clean areas of the murals. The spectroscopy measurements were carried out for a total of 30$60 \mathrm{~s}$ using the $40 \mathrm{kV}$ X-ray tube and another $30 \mathrm{~s}$ at $15 \mathrm{kV}$. In addition, an area of $1 \mathrm{~cm}^{2}$ was measured in the atmospheric environment. For the measured spectrum, the elements detected with high intensities in each color were compared against the background and were considered to have contributed to the measured color; these results were then used to tentatively identify the pigments that were used in the murals. XRF mapping for the paint layers in the murals was performed using a portable micro X-ray fluorescence spectrometer mounted with mapping equipment. The XRF mapping equipment(ELIO, Bruker, DEU) was used as the spectrometer, with a $40 \mathrm{kV} \mathrm{X-ray} \mathrm{tube} \mathrm{in} \mathrm{the} \mathrm{ambient} \mathrm{air,}$ and a $10 \times 10 \mathrm{~cm}^{2}$ area was mapped at $3 \mathrm{~mm}$ intervals every second.

\subsection{SEM-EDS}

To observe the particles in the pigments, a small region of the collected samples was magnified and observed using a stereomicroscope(SMZ18, Nikon, JPN), and then, based on the obtained results, scanning electron microscopy (SEM)(EM-30AX Plus, Coxem, KOR) and energy-dispersive X-ray spectroscopy(EDS)(Aztec one, Oxford, GBR) were used for elemental analysis. The EDS measurements were carried out at $20 \mathrm{kV}$, WD of $15 \mathrm{~mm}$, a spot size of 40 , and a measurement time of $100 \mathrm{~s}$.

\subsection{Raman spectroscopy}

Raman spectroscopy is a spectroscopic technique based on inelastic scattering of monochromatic light. Raman scattering refers to inelastic scattering due to energy loss or gain during the scattering when light passes through the medium. Raman spectroscopy can detect the Raman peaks specific to particular pigments at the particle level and identify the types of pigments. A Raman spectrometer(LabRAM ARAMIS, Horiba Scientific, JPN) was used in this study, and a $632.8 \mathrm{~nm}$ $(\mathrm{HeNe})$ laser with a $\times 500$ lens was used for the measurements.

\section{RESULTS AND DISCUSSION}

\subsection{Painting technique}

The Buseoksa Josadang murals were based on a yellow primer layer painted across the entire area, and the figures were painted directly on top of the background without a covered layer(Figures 2A and 2B). In the Joseon murals, the covered layer was usually painted across the entire area. The painting was carried out in the following order; the finish layer, primer layer, covered layer, and paint layer, followed by celadonite(a greyish green pigment) that was used to cover the entire area, and then the main paintings were painted again on top of celadonite. This painting technique is characteristic of many Joseon murals, such as the Geungnakjeon murals at Silleuksa, Jecheon, Daeungjeon murals at Jikjisa, Gimcheon, Youngsanjeon murals at Tongdosa, Yangsan(Han et al., 2011) and Geungnakjeon murals at Hwaamsa, Wanju(Wanju-gun and Sungbo Preservation Institute, 2018). However, in the Buseoksa Josadang murals, greyish green pigments were only used for the background, and thus, the murals are considered to have been created by a painting technique different from that used 

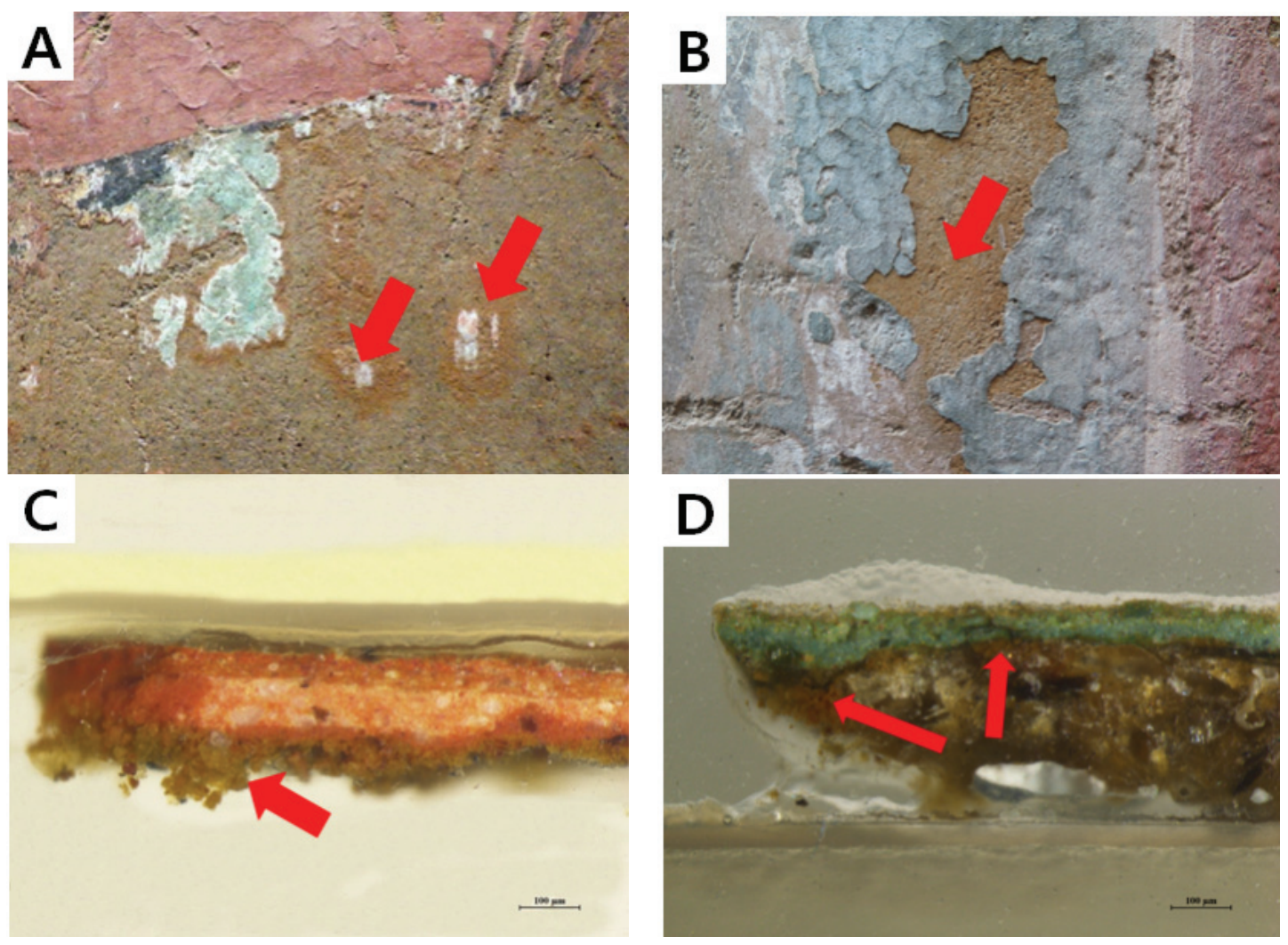

Figure 2. Paintings and layers of Josadang murals; (A) Peeled main painting area of BSJ-M-1, (B) Peeled surrounding area of BSJ-M-1, (C) Painting layer of main painting area of MSJ-M-1, (D) Painting layer of the surrounding area of BSJ-M-1.

in the Joseon period.

In Jasadang murals, two paint layers were found(Figures $2 \mathrm{C}$ and 2D). The second paint layer was painted directly on top of the first layer without any background and covered painting. It is presumed that repainting was carried out directly on top of the painting without any finish that otherwise would have removed the previous paint layer or the background painting.

\subsection{Pigments}

\subsubsection{Background}

In the background area, Fe was detected as the main element with trace amounts of $\mathrm{Si}, \mathrm{K}, \mathrm{Ca}, \mathrm{Ti}, \mathrm{Rb}, \mathrm{Sr}$, and $\mathrm{Zr}$; this appears to suggest that the background consisted of soil materials such as yellow ochre(Table 1, Figure 3A). Depending on the area, trace amounts of $\mathrm{Cu}, \mathrm{Hg}$, and $\mathrm{Pb}$ were also detected that appeared to be due to the pigments that remained after the paint layer fell off in that area.

\subsubsection{Greyish green}

Greyish green pigments showed a mixture of particles with varying colors from dark green to light green and the microscopic characteristics of typical celadonite. An XRF analysis of the greyish green area detected $\mathrm{Fe}$ as the primary element along with trace amounts of $\mathrm{K}$ and $\mathrm{Ca}$ (Table 1 , Figure 3B). Two painting layers were observed in the greyish-green area in the Josadang murals. An SEM-EDS analysis on each of the layers detected $\mathrm{Fe}$ as the main element in both layers together with traces of $\mathrm{K}, \mathrm{Al}, \mathrm{Si}$, and $\mathrm{Mg}$. Given these results, the greyish-green pigments in the Josadang murals are presumed to have used celadonite $\left(\mathrm{K}\left(\mathrm{Mg}, \mathrm{Fe}^{2+}\right)\left(\mathrm{Fe}^{3+}, \mathrm{Al}\right)\left[\mathrm{Si}_{4} \mathrm{O}_{10}\right]\left(\mathrm{OH}_{2}\right)\right)$ in both layers. However, a comparison of the particle size in the bottom and the top paint layers confirmed that pigment particles in the bottom layer were relatively larger and more uneven, clearly distinguishing these two layers(Figure 4). 
Table 1. XRF analyzed points and results

\begin{tabular}{|c|c|c|c|c|c|}
\hline \multirow{2}{*}{ Color } & \multirow{2}{*}{ Painting } & \multirow{2}{*}{ Analyzed point } & \multirow{2}{*}{$\begin{array}{c}\text { Major detected } \\
\text { elements }\end{array}$} & \multicolumn{2}{|c|}{ Estimated pigments } \\
\hline & & & & First layer & Second layer \\
\hline \multirow{6}{*}{ Background layer } & BSJ-1 & 7 & \multirow{6}{*}{$\mathrm{Fe}$} & \multirow{6}{*}{-} & \multirow{6}{*}{ Yellow ochre } \\
\hline & BSJ-2 & $9,15,24$ & & & \\
\hline & BSJ-3 & $2,3,4$ & & & \\
\hline & BSJ-4 & $3,17,18$ & & & \\
\hline & BSJ-5 & 1,12 & & & \\
\hline & BSJ-6 & $17,26,35,36$ & & & \\
\hline \multirow{6}{*}{ Greyish green } & BSJ-1 & $1,2,11,14$ & \multirow{6}{*}{$\mathrm{Fe}, \mathrm{K}$} & \multirow{6}{*}{ Celadonite } & \multirow{6}{*}{ Celadonite } \\
\hline & BSJ-2 & $1,2,13,14,23$ & & & \\
\hline & BSJ-3 & 1,20 & & & \\
\hline & BSJ-4 & $1,2,20$ & & & \\
\hline & BSJ-5 & $2,3,11$ & & & \\
\hline & BSJ-6 & $1,2,3,9,15,18,31$ & & & \\
\hline \multirow{6}{*}{ White } & BSJ-1 & 5 & \multirow{6}{*}{$\mathrm{Ca}, \mathrm{P}, \mathrm{Fe}$} & \multirow{6}{*}{ White clay } & \multirow{6}{*}{ Bone white } \\
\hline & BSJ-2 & 5,22 & & & \\
\hline & BSJ-3 & 17,18 & & & \\
\hline & BSJ-4 & 10,16 & & & \\
\hline & BSJ-5 & $4,7,8$ & & & \\
\hline & BSJ-6 & $21,22,29,34$ & & & \\
\hline \multirow{2}{*}{$\begin{array}{l}\text { Pale pink } \\
\text { (skin part) }\end{array}$} & BSJ-1 & $4,12,10,13,15,16$ & \multirow{2}{*}{$\mathrm{Ca}, \mathrm{Fe}, \mathrm{P}, \mathrm{Hg}, \mathrm{Pb}$} & \multirow{2}{*}{$\begin{array}{l}\text { White clay }+ \\
\text { Red ochre }\end{array}$} & \multirow{2}{*}{$\begin{array}{c}\text { Bone white }+ \\
\text { Cinnabar or } \\
\text { Vermilion }\end{array}$} \\
\hline & BSJ-6 & $5,6,7,24,27$ & & & \\
\hline \multirow{8}{*}{$\begin{array}{l}\text { Bright pink } \\
\text { (skin part) }\end{array}$} & BSJ-2 & $4,16,17,18$ & & & \\
\hline & BSJ-3 & 10 & & & \\
\hline & BSJ-4 & 6,7 & & & \\
\hline & BSJ-5 & 5 & $\mathrm{Fe} \quad \mathrm{Ca} \mathrm{P}$ & Red ochre & Bone white + \\
\hline & BSJ-3 & 13,19 & $1 \mathrm{c}, \mathrm{Ca}, 1$ & Red oche & Red ochre \\
\hline & BSJ-4 & 14 & & & \\
\hline & BSJ-5 & 15 & & & \\
\hline & BSJ-6 & $4,11,12,23$ & & & \\
\hline & BSJ-1 & $3,6,9$ & & & \\
\hline & BSJ-2 & 12 & & & \\
\hline Reddish Orange & BSJ-3 & $6,8,11,12,15,16$ & $\mathrm{Hg}, \mathrm{Pb}$ & $\begin{array}{l}\text { Cinnabar or } \\
\text { Vermilion/Minium }\end{array}$ & Bone white + \\
\hline & BSJ-4 & $4,12,15,19$ & & & \\
\hline & BSJ-5 & 10 & & & \\
\hline & BSJ-1 & 3 & & & \\
\hline & BSJ-2 & 3 & & & \\
\hline Gold color & BSJ-3 & 7 & $\mathrm{Au}$ & - & Gold \\
\hline & BSJ-4 & 3,5 & & & \\
\hline & BSJ-5 & 6 & & & \\
\hline & BSJ-2 & 10 & & Synthetic green & \\
\hline Green & BSJ-3 & 9,14 & $\mathrm{Cu}, \mathrm{Sn}, \mathrm{Zn} \mathrm{Pb}$ & tin and zinc & 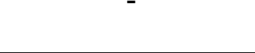 \\
\hline & BSJ-4 & 9 & $\mathrm{Cu}, \mathrm{Cl}$ & Paratacamite or & \\
\hline & BSJ-6 & $9,14,33$ & & Botallackite & - \\
\hline & BSJ-2 & 7 & & & Azurite/Bone white \\
\hline Blue & BSJ-3 & 5 & $C_{1}$ & & or \\
\hline Diue & BSJ-4 & 8,13 & $\mathrm{cu}$ & - & Azurite/Yellow \\
\hline & BSJ-6 & 8,13 & & & ocnre \\
\hline
\end{tabular}




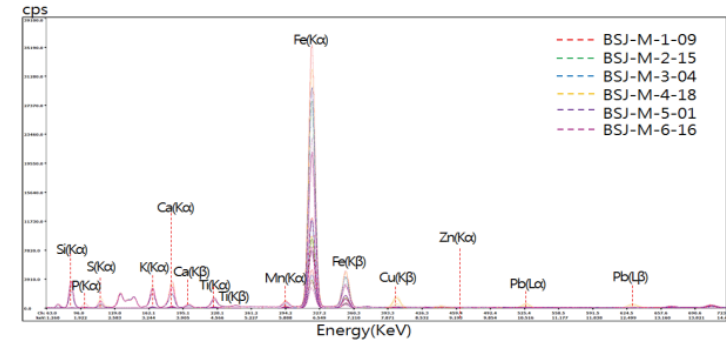

A

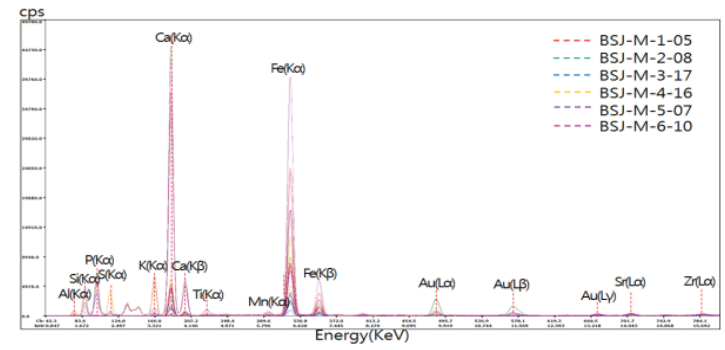

C

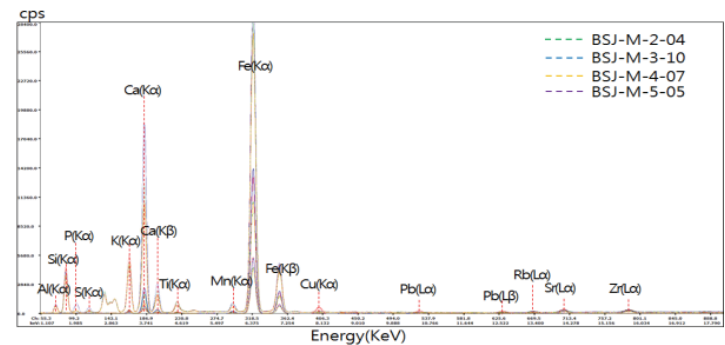

E

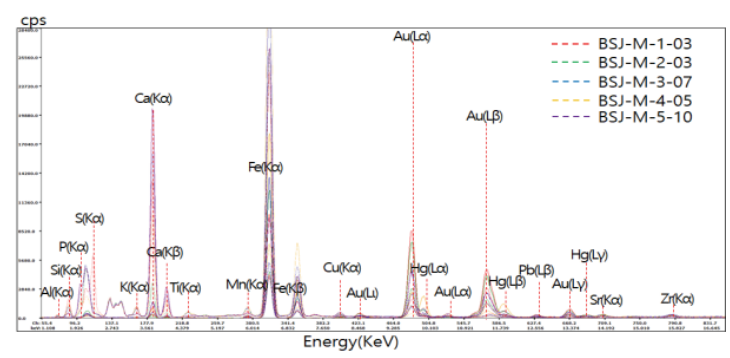

G

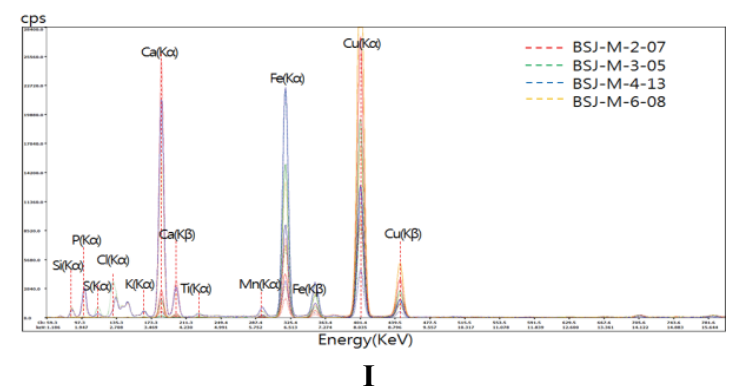

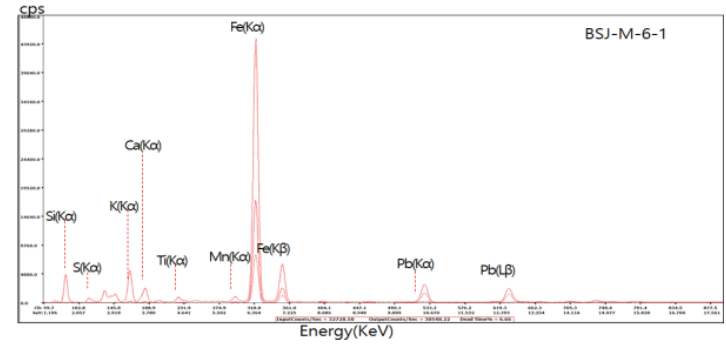

B

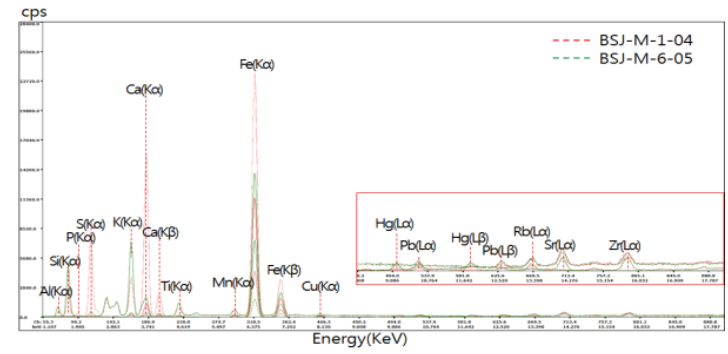

D

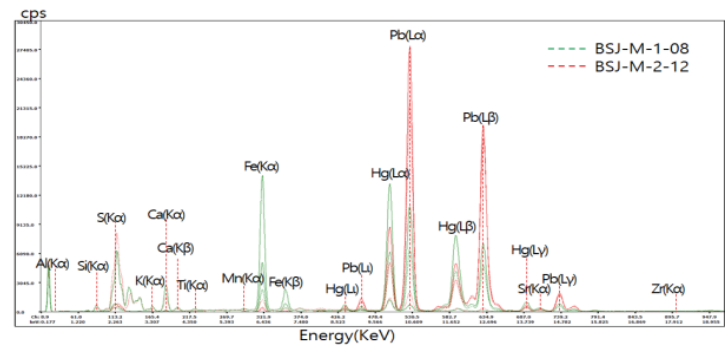

F

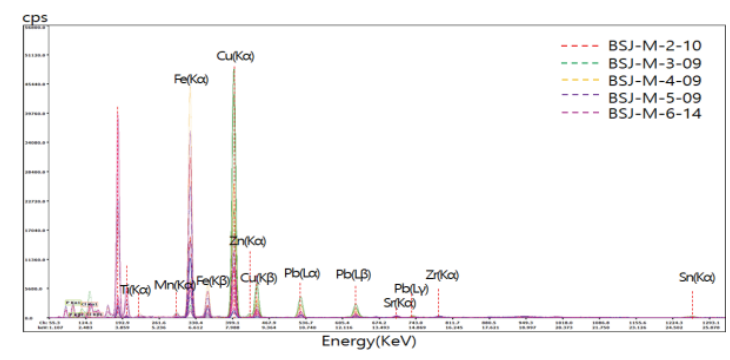

H

Figure 3. XRF spectra of each color; (A) Background layer, (B) Greyish green, (C) White, (D) Pale pink, (E) Bright pink, (F) Reddish orange, (G) Gold color, (H) Green, (I) Blue. 

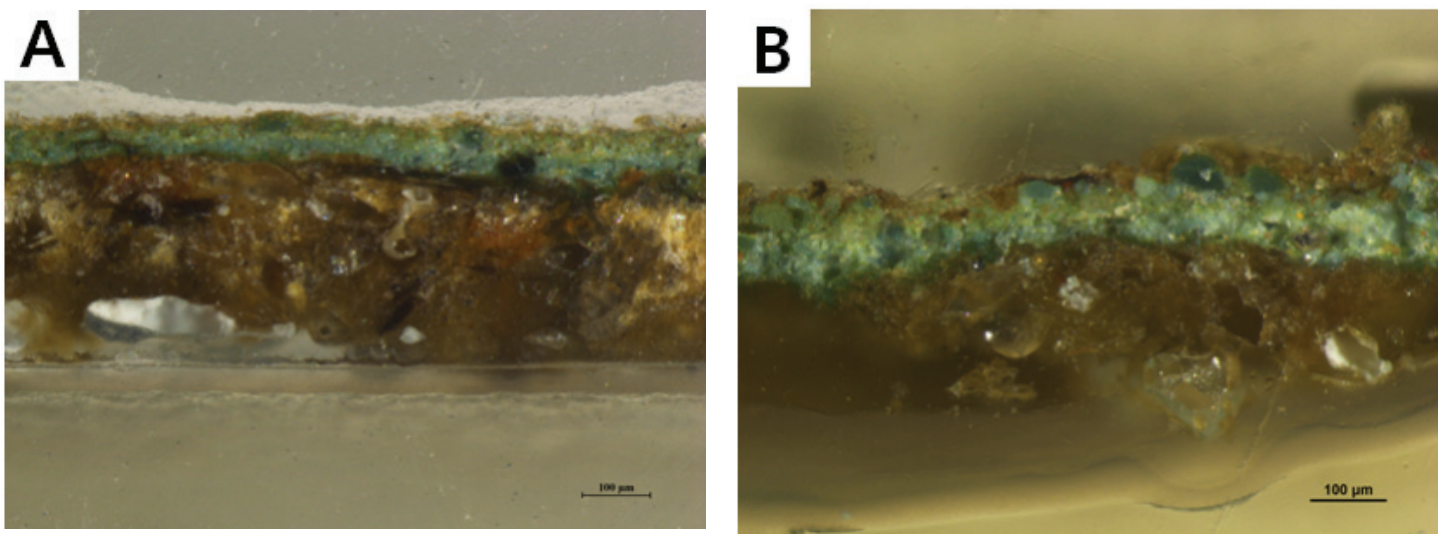

Figure 4. Particle size comparison between the greyish green pigments used in the repainting and the pigment used in the original painting; (A) Cross-sectional image of the repainting pigment from the BSJ-M-3 sample $(\times 135)$, (B) Cross-sectional image of the original painting pigment from the BSJ-M-3 sample $(\times 135)$.
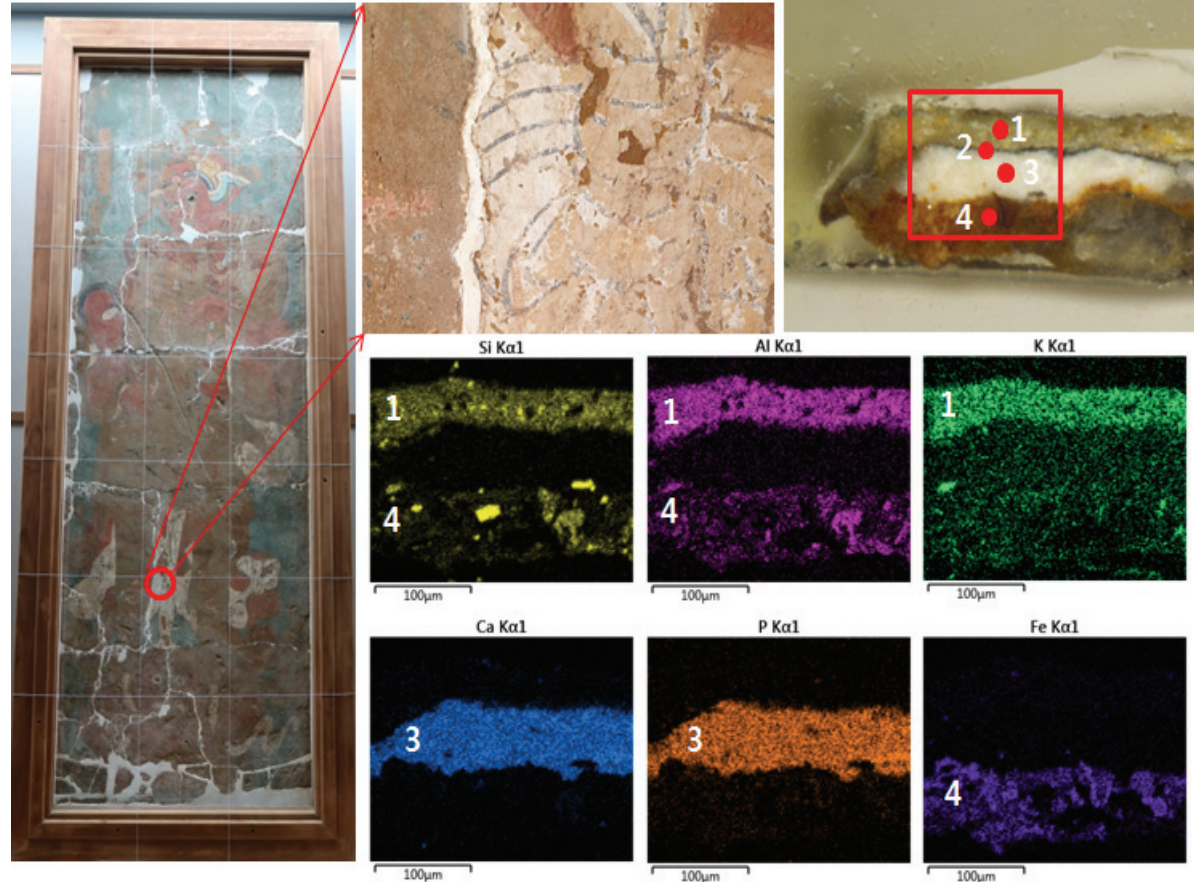

Figure 5. Cross-sectional and SEM-EDS mapping images of the white painting area of BSJ-M-3.

\subsubsection{White}

An XRF analysis of the white area detected $\mathrm{Fe}, \mathrm{Ca}, \mathrm{K}$, $\mathrm{Al}, \mathrm{Si}, \mathrm{P}$, and $\mathrm{S}$ with trace amounts of $\mathrm{Au}$ in some parts(Table 1, Figure 3C). Light elements such as Al, Si, K, and $\mathrm{Ca}$ are the typical constituents of white clay, and the white pigments present in the Josadang murals were presumed to originate from white clay. However, the intensities of $\mathrm{Ca}$ and $\mathrm{P}$ detected in the white area in the
Josadang murals were found to be higher than those of typical white clay, and the intensities of the two elements were higher in the area where the bottom layer was exposed. These characteristics were found in for all six murals. The cross-section of the white pigment sample collected from BSJ-M-3 was analyzed(Figure 5), finding four layers of white/black/white/yellow colors from top to bottom. Since there was a black layer between the white layers, it was 

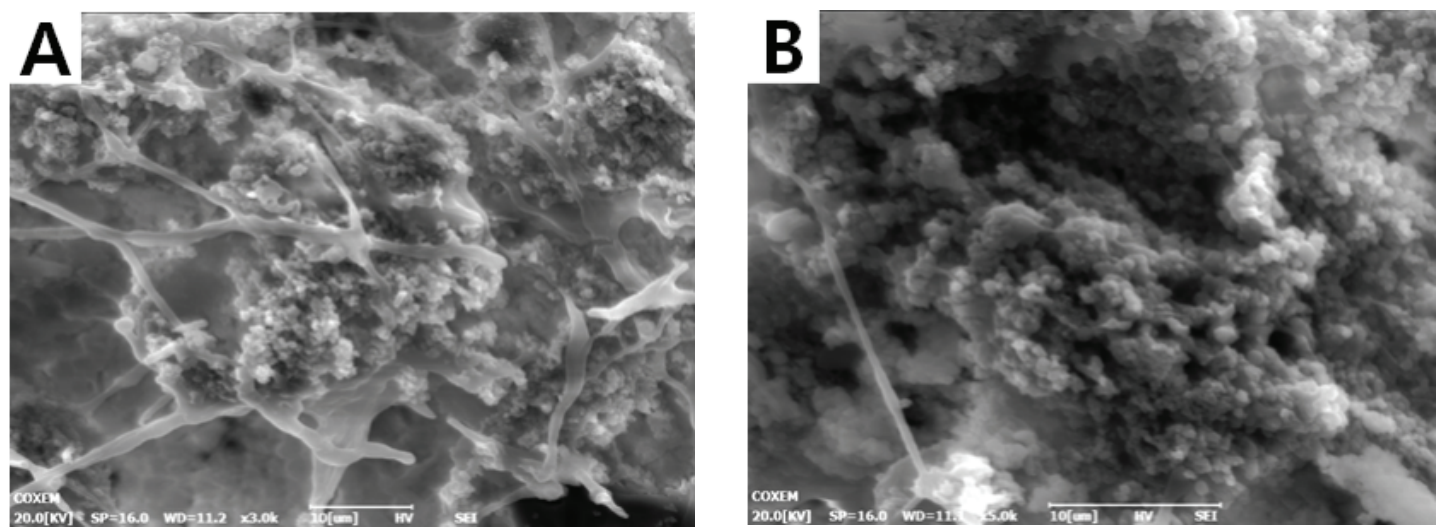

Figure 6. SEM images of the white pigment particles of the inner painting in BSJ-M-3 at $\times 3000$ (A), and $\times 5000$ (B).

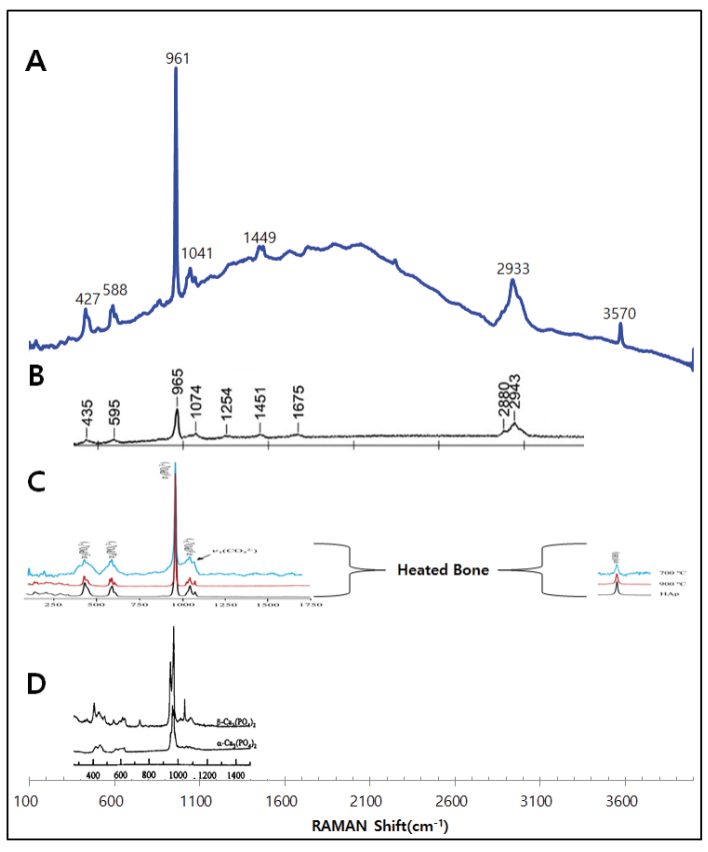

Figure 7. Comparison of the Raman spectra of the white pigment from Jasadang murals (A) and of bone containing collagen (B), heated bone $(\mathrm{C})$, and $\mathrm{Ca}_{2}(\mathrm{PO})_{4}(\mathrm{D})$.

presumed that the white area was painted at another point in time, and not consecutively at the same time period. An EDS analysis of each layer detected $\mathrm{Si}, \mathrm{Al}$, and $\mathrm{K}$ as the main elements in the top white layer and $\mathrm{Ca}$ and $\mathrm{P}$ as the main elements in the bottom white layer, confirming that the two white layers came from different materials. In the area where $\mathrm{Ca}$ and $\mathrm{P}$ were detected, the pigment particles were nanoscale and very small(Figure 6). These characteristics are observed when the materials are fired. Comparison to the data obtained in the previous studies showed that the Raman spectroscopy confirmed that this spectrum was similar to that of the artificially produced $\left[\mathrm{Ca}_{2}\left(\mathrm{PO}_{4}\right)_{2}\right]$, bones containing collagen, and materials taken from burned animal bones(Figure 7) (Bordes et al., 2017; Marques et al., 2018; Jillavenkatesa and Condrate Sr, 1998).

Natural white materials with $\mathrm{Ca}$ and $\mathrm{P}$ as the main elements, include fluorapatite $\left[\mathrm{Ca}_{5}\left(\mathrm{PO}_{4}\right)_{3} \mathrm{~F}_{2}\right]$, which is a major component of teeth and bones. Fluorapatite mostly comes from Canada, Mexico, Brazil, Russia, Japan, and Myanmar, and is not produced in Korea(Doopedia, 2020). Fluorapatite is artificially obtained by firing animal bones, and the primary component of the material obtained using this method is $\left[\mathrm{Ca}_{2}\left(\mathrm{PO}_{4}\right)_{2}\right]$. White pigments that consist of this component are called bone white and were used in paintings with the paper or parchment background in medieval Europe(Gettens and Stout, 1996). Typical bone white is known to be a greyish white or a somewhat sandy powder. White pigments used in the Josadang murals are pure with very high $\mathrm{Ca}$ and $\mathrm{P}$ contents and almost no light elements that are usually detected in minerals. Considering these results, it is highly likely that the white pigments in the Buseoksa Josadang murals have originated from the white powder obtained by burning animal bones. The white pigments that have been traditionally used in Korea include white clay, soil pigment, white lead, and a $\mathrm{Pb}$ pigment. Until the early Joseon period, white clay rather than white lead was often used as a white pigment for murals or dancheong. The use of white lead increased towards the late Joseon period; however, white clay was also used consistently for mural backgrounds. By contrast, the use of white pigments 
containing $\mathrm{Ca}$ as the main element has not been identified for painting materials and was confirmed for the first time in the Josadang murals. For murals or paintings from the same period in Japan and China, kirakumen No. 115 garuda(Treasure) in Shōsōin, it was confirmed that apatite $\left[\mathrm{Ca}_{5}\left(\mathrm{PO}_{4}\right)_{3}(\mathrm{OH}, \mathrm{Cl}, \mathrm{F})\right]$ was used in Japan(Kimura and Naruse, 1988), but is not found in China.

\subsubsection{Skin color}

The faces of the figures in the Sakra(BSJ-M-1) and Brahmā(BSJ-M-6) murals used pale pink skin colors and the Virūọhaka(BSJ-M-2 to 5) murals used bright pink. For the six murals, $\mathrm{Fe}, \mathrm{Ca}$, and $\mathrm{K}$ were detected as the main elements along with light elements such as $\mathrm{Ti}, \mathrm{Mn}, \mathrm{Rb}, \mathrm{Sr}, \mathrm{Zr}, \mathrm{Al}$, $\mathrm{Si}$, and $\mathrm{P}($ Table 1, Figures 3D and 3E). These elements are usually found in the soil; thus, soil pigments appear to have been used in the skin colors of the six murals. However, a comparison of the elemental contents detected in the skin colors of these murals showed that the largest difference was observed for the Fe content. BSJ-M-2-5, featuring Virūḍhaka, showed stronger intensities of $\mathrm{Fe}$ than BSJ-M-1 and BSJ-M-6, featuring Śakra and Brahmā. Furthermore, trace amounts of mercury $(\mathrm{Hg})$ were also detected in the Śakra and Brahmā murals unlike for the Virūḍhaka murals. The XRF mapping image of the Brahmā's face showed that mercury $(\mathrm{Hg})$ was distributed in certain areas of the face(Figure 8). In the Brahmā mural, mercury( $\mathrm{Hg})$ was found distributed in a part of the entire area rather than across the entire area.

The cross-sections of the samples collected from the faces of BSJ-M-1 and BSJ-M-3 confirmed the presence of two

paint layers in both murals(Figure 9). Meanwhile, $\mathrm{Si}, \mathrm{Al}$, and Fe were mixed at the top layer of BSJ-M-1, with a low proportion of $\mathrm{Fe}$. At its bottom layer, $\mathrm{Ca}$ and $\mathrm{P}$ were mixed with trace amounts of $\mathrm{Hg}$. XRF mapping also showed a low content of $\mathrm{Hg}$, partially in the face. For the pigments in BSJ-M-3, three paint layers were observed: Fe was the main element at the top layer, $\mathrm{Si}$ and $\mathrm{Al}$ were concentrated at the 2nd layer, and $\mathrm{Ca}$ and $\mathrm{P}$ at the 3rd layer. To summarize, different pigments were used in the top and bottom paint layers of these murals. Calcium phosphate white pigment $(\mathrm{Ca}$,

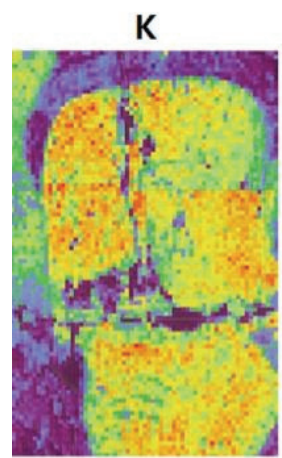

Fe

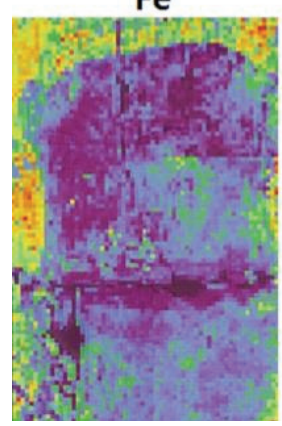

Figure 8. XRF mapping images of face part at BSJ-M-6.

$\mathrm{Ca}$

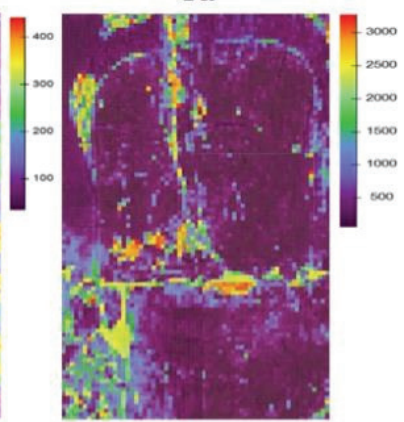

$\mathrm{Hg}$

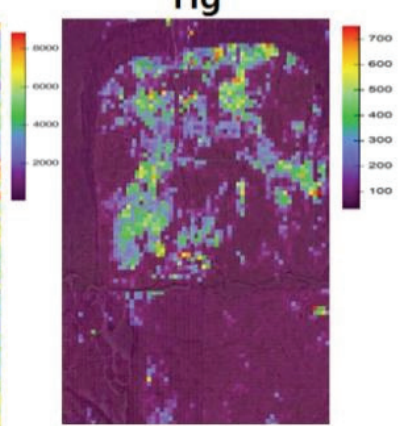

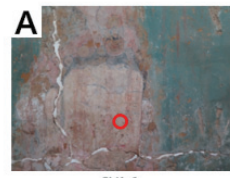
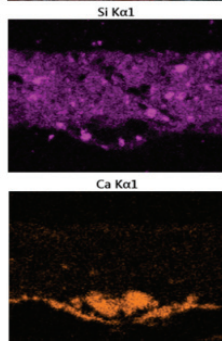
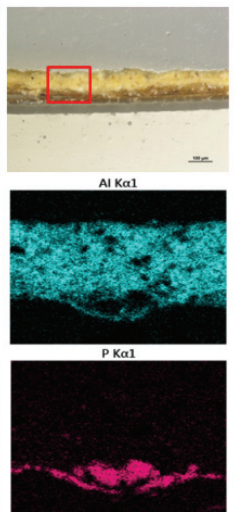
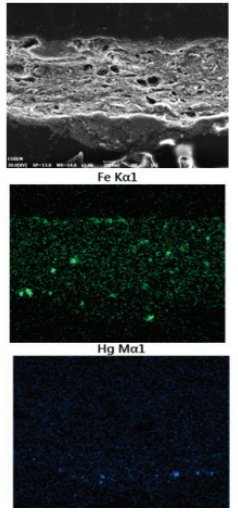
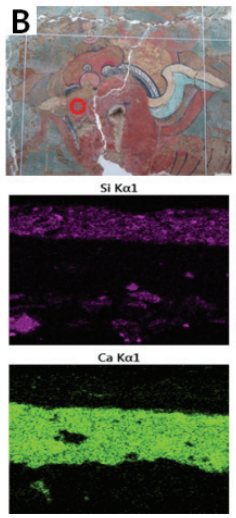
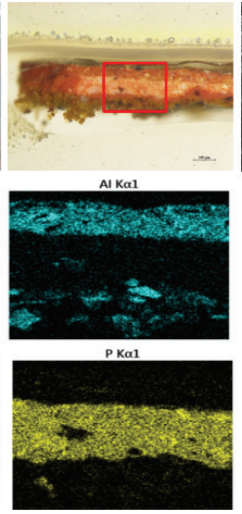
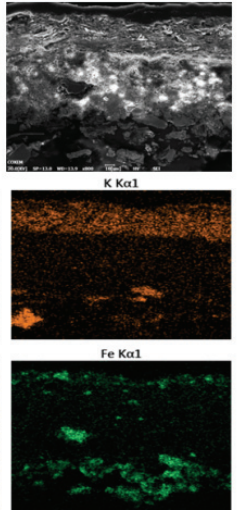

Figure 9. Cross-sectional and SEM-EDS mapping images of face part; (A) BSJ-M-1, (B) BSH-M-3. 
P) + cinnabar $(\mathrm{HgS})$ changed to white clay + red ocher in BSJ-M-1, whereas calcium phosphate white pigment( $\mathrm{Ca}, \mathrm{P})$ + red ocher changed to red ocher in BSJ-M-3.

\subsubsection{Reddish orange}

From visual observation, it was observed that reddishorange color was mostly painted on top of orange pigments. An XRF analysis showed $\mathrm{Hg}$ and $\mathrm{Pb}$ as the main elements; $\mathrm{Fe}, \mathrm{Ca}, \mathrm{Si}, \mathrm{P}, \mathrm{K}$, and Ti were detected together, depending on the area(Table 1, Figure 3F). An observation of the cross-section in this area confirmed four paint layers(Figure 10). From top to bottom, the 1st and 2nd layers consisted of reddish-orange $(\mathrm{Hg})$ and orange $(\mathrm{Pb})$ while the 3rd layer was reddish-brown with a mixture of $\mathrm{Ca}, \mathrm{P}$, and $\mathrm{Fe}$. In the 4th background layer, Fe was detected as the main element. Hence, it is presumed that the 3rd layer was the original paint layer mixed with white pigments containing $\mathrm{Ca}$ and $\mathrm{P}$ and red pigments containing $\mathrm{Fe}$, while the 1st and 2nd layers were the repainting layers for which minium $\left(\mathrm{Pb}_{3} \mathrm{O}_{4}\right)$ and cinnabar or vermilion were used.

\subsubsection{Gold}

Gold was used on top of the red paint layer only, and given the ruggedness or cutoffs of the surface, it is possible that gold foils were used. In the gold area of all the murals,
$\mathrm{Au}$ was commonly detected as the main element along with $\mathrm{Fe}, \mathrm{Ca}$, and $\mathrm{P} . \mathrm{Hg}$ and $\mathrm{Pb}$ were also detected together, depending on the area(Table 1, Figure 3G). Given that impurities such as $\mathrm{Ag}$ and $\mathrm{Ni}$ were not detected with the gold, it is presumed that gold leaves were used. Analysis of the intensities of the elements detected in the gold area shows that higher intensities were observed for $\mathrm{Ca}, \mathrm{Fe}$, and $\mathrm{P}$. Microscopy also revealed a yellow background layer in the gold foil background, a pink layer, which is presumed to be the original paint layer, and red pigments on top of the gold foils in some parts. Given these results, it is highly probable that gold foils were the painting materials used in the original painting.

\subsubsection{Green}

In the green area in the Josadang murals, it was observed that dark green pigment particles were in some cases placed on top of the light green layer, suggesting that two types of pigments were used. Furthermore, an observation of the green pigment paint layer showed that with the exception of except for BSJ-M-6, the murals were painted in the order of light green/greyish green/white or light green/greyish green/pink/ yellow. The greyish-green pigments were not used for covering the entire area but only as the background pigments for the green area in the Josadang murals. This suggests that
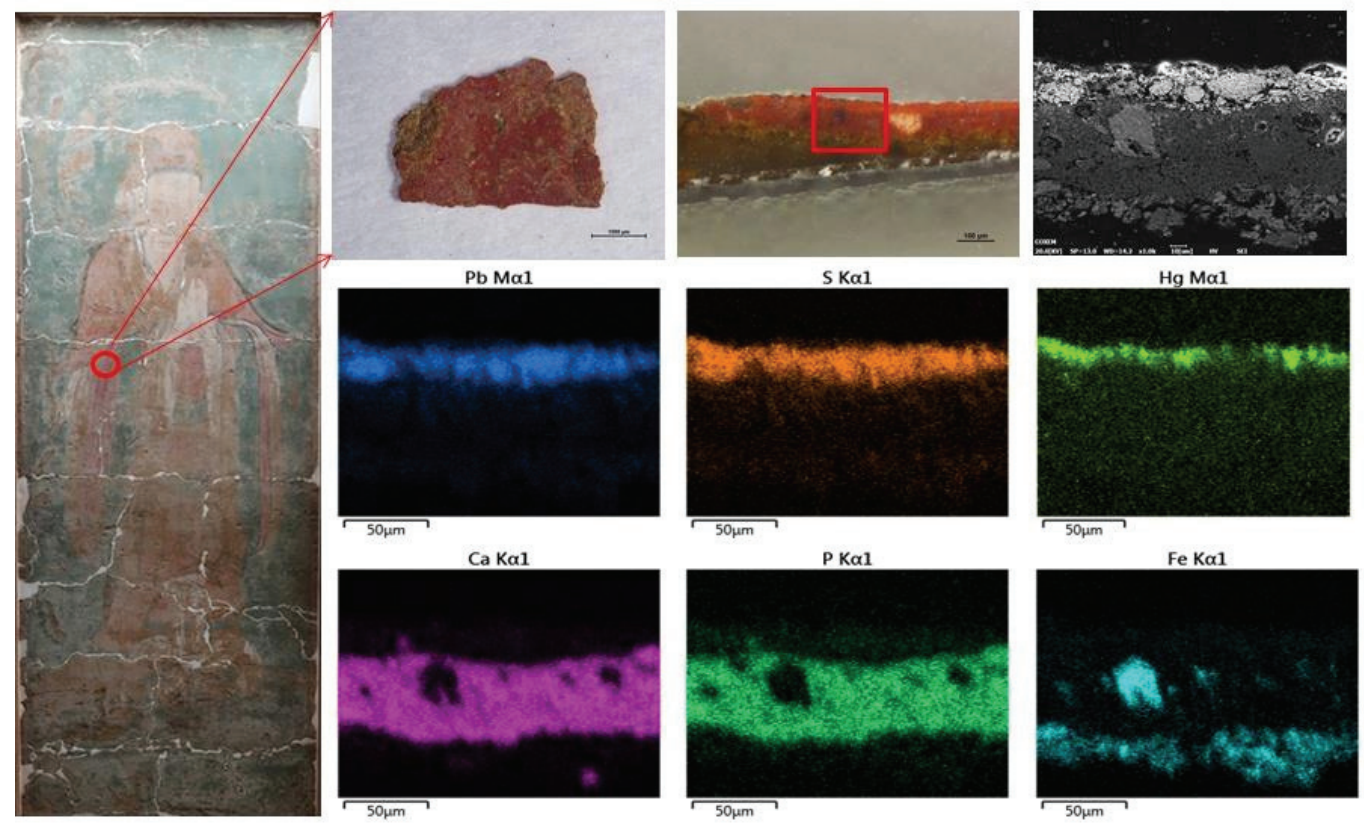

Figure 10. Cross-sectional and SEM-EDS mapping images of clothes of BSJ-M-1. 
the murals have a unique painting technique that has not been identified in Korea's other dancheong and murals.

In most of the light green areas in the Josadang murals, $\mathrm{Pb}$ and $\mathrm{Sn}$ were detected together with $\mathrm{Cu}$, which is the main element for green; in some parts, $\mathrm{Zn}$ was also detected(Table 1, Figure $3 \mathrm{H}$ ). Almost no green pigments identified in traditional Korean dancheong or murals used malachite, which is a natural pigment. Rather, most of them used artificially created pigments based on copper(Song, 2018). Traditional copper alloys are composed of bronze and brass, containing $\mathrm{Cu} / \mathrm{Sn} / \mathrm{Pb}$ and $\mathrm{Cu} / \mathrm{Zn} / \mathrm{Pb}$, as the main elements, respectively. As revealed in the usage trend in the Joseon period, bronze transitioned into brass after the mid- and late 17th century, probably because zinc was much cheaper than tin during this period(Jang et al., 2015). Coinciding with this transition, pigments containing $\mathrm{Cu} / \mathrm{Zn} / \mathrm{Pb}$ emerged in green pigments used in the Joseon period dancheong after the 17th century, but patina containing $\operatorname{tin}(\mathrm{Sn})$ was detected less frequently(Song, 2018). Hence, it is presumed that the green pigments in the Josadang murals were artificially produced, and the detection of $\mathrm{Sn}$ and $\mathrm{Zn}$ suggests that the top layer was repainted, sometime after the 17th century. Since $\mathrm{Cu}$ and $\mathrm{Cl}$ are detected in dark green lotus leaves, it is concluded that copper chloride green pigments such as paratacamite or botallackite could have been used.

\subsubsection{Blue}

An XRF analysis of the blue area detected $\mathrm{Cu}, \mathrm{Ca}$, and $\mathrm{Fe}$ as the primary elements with trace amounts of $\mathrm{Ti}$ and Mn(Table 1, Figure 3I). The blue pigments have particles with a size of 10-30 $\mu \mathrm{m}$ and were relatively larger. The pigments showed bluish glaze colors and cracked particles; thus, they are considered to have the characteristics of mineral particles(Figure 11). Hence, blue pigments came from azurite that has $\mathrm{Cu}$ as the main element. Since the blue pigment was painted on the white paint layer containing $\mathrm{Ca}$ and $\mathrm{P}$ or yellow primer layer, this layer is presumed to be the original paint layer.

\section{CONCLUSION}

1. Buseoksa Josadang murals consisted of one background layer and two paint layers, and they were repainted on the top of the existing paint layers without any surface polishing or new background layers. The layers were divided into the background layer for which greyish green pigments were used only for the background area, and the paint layer where the colors were painted. This differs from a typical Buddhist mural painting technique in the Joseon period where greyish green covered the entire area.

2. It was confirmed that different pigments were used for all of the colors in the two paint layers. It was estimated that
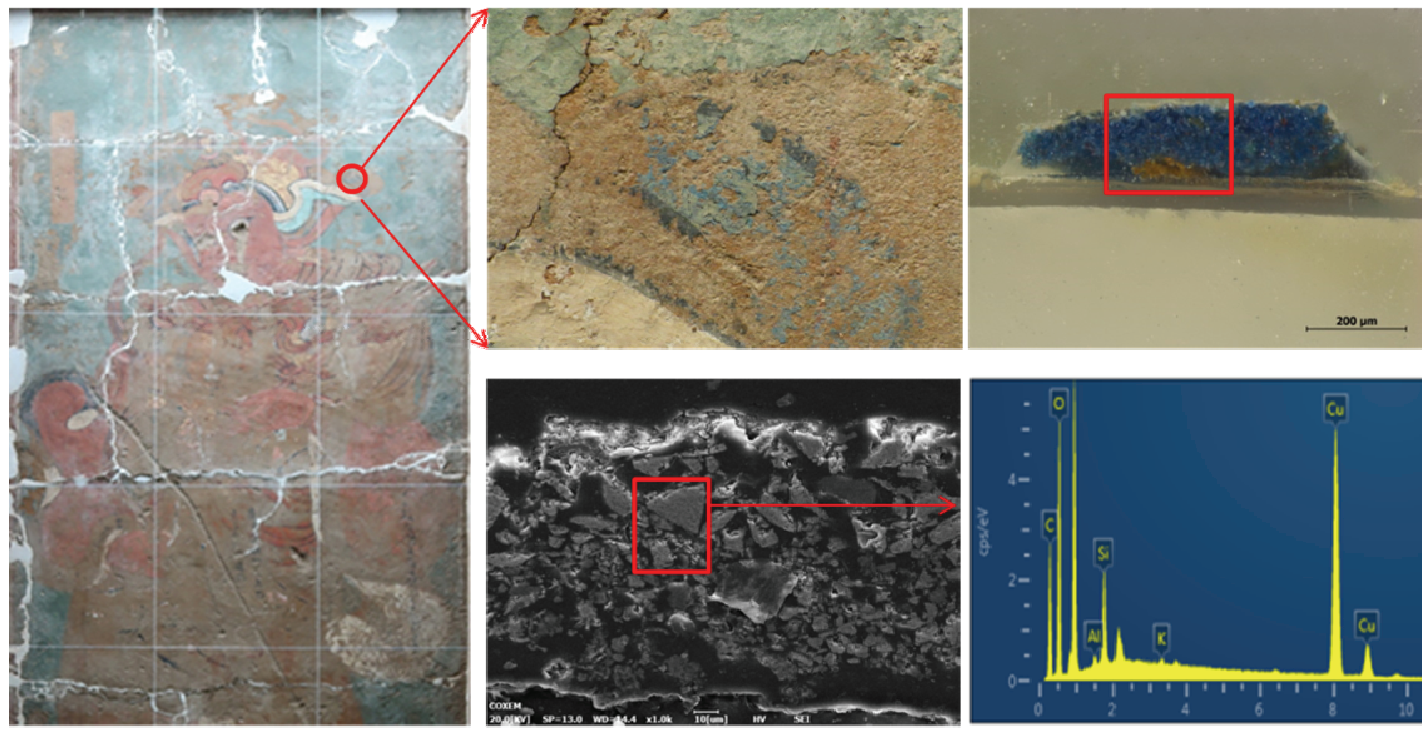

Figure 11. Cross-section and SEM-EDS images of blue part of BSJ-M-3. 
celadonite, white clay, red ochre, cinnabar and minium, synthetic green pigment containing tin and zinc, paratacamite or botallackite were used in the upper layer. In addition, bone white, celadonite, red ochre, azurite, cinnabar or vermilion and gold foil were identified in the bottom layer.

3. Especially, white pigments containing $\mathrm{Ca}$ and $\mathrm{P}$ were used for painting the base layer with blue or mixed pigments such as skin color and red color in the bottom layer.

4. It is not possible to clearly distinguish the timing of the painting for all of the pigments of each color. However, tin and zinc were detected together in green pigments that are presumed to have been repainted, and they are important guiding elements that help to determine the repainting period. It is highly probable that the Josadang murals were repainted above the original paint layer after the 17th century. Furthermore, greyish green pigments were used to paint only the background in the green area, which is a unique painting technique that has not been used in conventional dancheong or murals.

5. Since the Korean artifacts where pigments from the Goryeo period can be identified are only limited to Goryeo Buddhist paintings, almost no information has been revealed about the pigments used during the Goryeo period. It is estimated that the Buseoksa Josadang murals were painted between the late Goryeo period and the early Joseon period, and the results from this analysis are expected to serve as an important reference for understanding the use of the pigments in the Goryeo period. Specifically, the use of calcium phosphate white pigments containing calcium and phosphorus in the Korean traditional paintings has been confirmed for the first time, which is highly significant for the study of painting materials.

\section{ACKNOWLEDGMENTS}

This work was carried out as a part of the $<$ Scientific research of Buseoksa Josadang murals $>$ project, which was led by the Korea Creative Content Agency, CON-TECH, University Enterprise, Korea National University of Cultural Heritage. Also we express our gratitude to the Haisung Conservation of Heritage. co. Ltd.

\section{REFERENCES}

Bordes, L., Prinsloo, L. C., Fullagar, R., Sutikna, T., Hayes, E., Jatmiko, Saptomo, E. W., Tocheri, M. W. and Roberts, R.G., 2017, Viability of raman microscopy to identify micro-residues related to tool-use and modern contaminants on prehistoric stone artefacts. Journal of Raman Spectroscopy, 48(9), 1212-1221.

Buseoksa, Yeongju-si and Haisung conservation science of heritage. co. Ltd., 2018, Research on the scientific preservation status of mural paintings and report on the production of photographic edition (a display replacement) in Buseoksa, 125-303. (in Korean)

Cho, N.C., Hong, J.W., Moon, H.S. and Hwang, J.J., 2000, The analysis study of mural painting pigments at Pongjongsa Kuknakjon(II). Conservation Science Studies, 21, 119-143. (in Korean with English abstract)

Chun, Y.G. and Lee, C.H, 2011, Pigment analysis for wall paintings according to verification of penetration depth for X-ray: Ssanggyesa Daeungjeon(Main hall of Ssanggyesa temple) in Nonsan. Journal of Conservation Science, 27(3), 269-276. (in Korean with English abstract)

Chun, Y.G., Kim, W.G., Jo, Y.H., Han, D.R., Kim, S.D. and Lee, C.H., 2009, Pigment analysis and nondestructive deterioration diagnosis of the wall paintings in Gwanyongsayaksajeon(Yaksajeon hall of Gwanyongsa temple), Changnyeong, Korea. Journal of Conservation Science, 25(4), 383-398. (in Korean with English abstract)

Doopedia, 2020, apatite, http://www.doopedia.co.kr/doopedia/ master/master.do? method=view\&MAS IDX=1010130008 99334 (January 20, 2020) (in Korean)

Gettens, R.J. and Stout, G.L., 1996, Painting materials. Dover Publication Inc, New York. 99.

Han, M.S., Lee, H.H. and Kim, J.H, 2011, A scientific analysis of ancient pigments on wall paintings at Yeongsanjeon in Tongdo temple using a field-XRF. MUNHWAJAE Korean Journal of Cultural Heritage Studies, 44(3), 132-149. (in Korean with English abstract)

Hong, J.W. and Chung, K.Y., 1992, X-ray diffraction analysis of Kumsansa mural painting and dan-chong. Conservation Science Studies, 13, 59-68. (in Korean with English abstract)

Jang, S.B., Cho, N.C. and Kang, H.T., 2015, Study on the materials characteristics of Sangpyeongtongbo coins and Joseon dynasty using chemical compositions and microstructures. Journal of Conservation Science, 31(3), 319-330. (in Korean with English abstract)

Jillavenkatesa, A. and Condrate Sr, R.A., 1998, The infrared and raman spectral of $\beta$ - and $\alpha$ - tricalcium phosphate $\left[\mathrm{Ca}_{2}\left(\mathrm{PO}_{4}\right)_{2}\right]$. An International Journal for Rapid 
Communication, 31(8), 1619-1634.

Kimura, N. and Naruse, M., 1988, Annual report of the office the Shosoin treasure house. Shosoin Annual Report, 10, 61-75. (in Japanese)

Marques, M. P. M., Mamede, A. P., Vassao A.R., Makhoul C., Cunha, E., Concalves, D., Parker, S.F. and Batista de Carvalho L.A.E., 2018, Heat-induced bone diagenesis probed by vibrational spectroscopy. Scientific Reports, 8 , 15935.

Son, Y., Kang, D.I., Lee, H.S. and Lee, H.H., 2013, Comparative study on the pigments applied on the wall paintings of temple in 18-19C. Journal of Conservation Science, 29(4), 445-450. (in Korean with English abstract)

Song Y.N., 2018, Materials characteristics of pigments on dancheong in Joseon dynasty. Ph.D. dissertation, KongJu National University, Gongju. (in Korean with English abstract)

Wanju-gun and Seongbo Perservation Institute, 2018, A report on the records of Dancheongjeon hall and the conservation project of mural paintings in Hwaeamsa temple, 324-330 (in Korean) 